\title{
CONSIDERING COMPLEXITIES IN UNIQUE AFRICAN PLANNING APPROACHES: ABSTRACTING THE ROLE OF AFRICAN URBAN RESIDENTS
}

\author{
SELNA CORNELIUS, JAKO VIVIERS, \\ JUANEE CILLIERS \& CHRISTI NIESING \\ Urban and Regional Planning, Research unit for Environmental Sciences and Management, \\ North-West University, South Africa
}

\begin{abstract}
Africa is currently the fastest urbanising region in the world and has subsequently become the centre of continuously growing attention from planning practitioners and academics. Many of these scholars argue for a unique African planning approach in light of the failure of the African urban landscape to emulate Western models of urbanisation. However, whilst practitioners and academics are deliberating concepts like decolonisation and African urbanism, African urban residents have been labouring nonstop to create sustainable living environments and meaningful lives for themselves. This paper aims to showcase how these residents have proven themselves to be active agents in constructing sustainable human settlements rather than simply being passive victims of relentless structural processes beyond their control. It argues the failure of unique African planning approaches and decolonisation attempts to recognise and more importantly, incorporate the solutions provided by the said African residents, because of the inherent Western ideals and ways of thinking guiding global planning approaches. The paper employs theory-based sampling as part of a qualitative inquiry into African urbanism, decolonisation and sustainable human settlement development, before turning to case studies in South Africa and Zambia to consider the complexities within these concepts and support the line of argument. The subsequent discussion begs the question of the role and interference required from planning practitioners and academics within the rapidly changing African urban landscape. It also explores the causative position of African residents in creating sustainable human settlements, highlighting the instances where they have created unique solutions to planning problems and have shaped the urban landscape to suit their own needs and circumstances, challenging Western rationalities underpinning African planning approaches. The paper concludes that abstracting the role of African urban residents in creating a unique African planning approach, may hold potential to create more sustainable and just human settlements in Africa.
\end{abstract}

Keywords: African urbanism, decolonisation, unplanned settlements, community-based planning, reblocking.

\section{INTRODUCTION}

Sometime during the year 2007, the world population became predominately urban for the first time in history [1], [2]. Africa, as part of the developing world, has experienced the highest urban growth rate during the past 20 years [3], [4] and has consequently become the centre of continuously growing attention from planning practitioners and academics. Notwithstanding the fact that this dramatic transformation in the world urban environment will be significant to both the global North and global South, the emphasis of this paper will be on that part of the world where these changes will likely have the most profound and visible effect, i.e. the global South and more specifically Africa [5].

Contrary to traditional Western urbanisation trends that were accompanied by inclusive growth within the Western urban landscape [6], Africa's structural transformation failed to keep up with urbanisation trends [4]. This consequently resulted in the proliferation of land invasion, spatial segregation, informal and unplanned settlements, slum-like urban environments, a high rate of urban poverty and rapidly increasing inequality [4]. 
Further to this, Watson [7], expressed concern that urban planning worldwide is beginning to reveal an alarming and increasing dichotomy between current planning approaches and the mounting challenges elicited by rapid urbanisation, particularly (but not limited to) noticeable in African cities and cities of the global South. Subsequently, Africa became the subject of increasing discourse from planning practitioners and academics [5], [8], seeking solutions to this barrage of planning challenges. Several of these scholars argue for a unique African planning approach [7], [9], [10], to address the said challenges of informality, unplanned settlements and slum conditions, especially in light of the failure of the African urban landscape to emulate Western models of urbanisation and the resulting urban planning solutions.

However, whilst practitioners and academics are deliberating concepts like decolonisation, African new urbanism, collaborative planning, rural-urban migration, the heritage of segregation, land invasion and the creation of sustainable human settlements, residents within unplanned and informal settlements have been labouring non-stop to create sustainable living environments and meaningful lives for themselves [10], [11]. This begs the critical question of the role and interference required from government, planning practitioners and academics within the rapidly changing African urban landscape and the resulting unplanned settlements [7], [12], [13].

This paper therefore aims to refrain from focussing its discussion on the challenges facing the rapidly urbanising and transforming African urban landscape, by rather converging on discussions concerning the unprejudiced reconsideration of the causative role of African residents as active agents in constructing sustainable human settlements instead of simply being passive victims of relentless structural processes beyond their control. The ensuing sections purpose to reflect on the lingering planning prejudice, briefly outline the current discourse on the African urban reality, argument for a metamorphism in abstracting the causative role of African urban residents in creating new planning approaches and a mind shift towards a metamorphism in the IQ of planning.

\section{NOT “DONALD TRUMPING” THE INFLUX}

\section{“Whether it's a ban or not, it's keeping 'bad people' out”-Donald Trump, 2017}

The current inundating influx of people to cities and seeming unsurmountable planning challenges awaiting the present and next generations of urban planners in Africa and the global South may leave many a planner, whether academic or practitioner, with a feeling of despondency and grappling for easy answers and quick solutions whilst reverting to traditional ways of plan making [14]. The succeeding discussion confirms that the statistics, especially regarding informality and slum-like urban environments, are dooming, the planning environment extremely challenging, and the threat to sustainable urban planning very real especially (but not exclusively) referring to the African urban landscape.

The subsequent sections also enquire into the planning professions' response to this ostensibly gloomy picture.

\subsection{The urbanisation "reality check"}

The rate of urbanisation is increasing in both developed and developing countries [1]. Currently, the most urbanised regions in the world comprise North America (82\%), Latin America and the Caribbean (80\%) and Europe (73\%), with Africa and Asia remaining mostly rural exhibiting urban populations of $40 \%$ and $48 \%$ respectively [1]. This, however, may be a misleading statistic as Africa and Asia are currently urbanising more rapidly than all the 
other regions in the world and are projected to become $56 \%$ and $64 \%$ urban, respectively, by 2050 [1].

Africa, as part of the developing world, has experienced the highest urban growth rate during the past 20 years at a rate of $3.5 \%$ per year [2], [3]. This might seem insignificant, but it should be noted with some concern that the rate of urbanisation in Africa, as in the case with Asia, transpired twice as fast as it did in Europe [15]. According to a report in 2014 by the Department of Economic and Social Affairs of the United Nations [1], it took Europe 110 years to transform from $15 \%$ urban in 1800 , to $40 \%$ in 1910 . Africa, in contrast, has achieved the same transformation in 60 years, virtually half the time it took Europe.

\subsection{Contextualising the African urban landscape}

In Africa, as with many other developing countries in the global South, the urbanisation rate trumped those of developed countries during the past couple of decades, but did not correspondingly parallel the economic growth rate that were associated with the Western urbanisation trends [16]. Pending this unprecedented rapid transformation of the African urban landscape, several scholars have expressed their concern during the past decade about the significance of these accelerated changes for the global South and more specifically for Africa. Marx et al. [17] and Watson [9] inter alia warns that the said urban changes are transpiring in urban landscapes ravaged by poverty and unemployment, where governments are least equipped to provide urban infrastructure and urban residents are least able to afford it.

Further to this and contrary to traditional Western urbanisation trends that were accompanied by inclusive growth within the Western urban landscape [6], Africa's structural transformation failed to keep up with urbanisation trends [3]. The inexorable consequence has been the rapid growth of unplanned and informal settlements, accelerated land invasion, poor-quality housing, lack of adequate living space, slum-like living environments, a high rate of urban poverty and rapidly increasing inequality in the African urban landscape [4].

Watson [5] further strongly argues that rapid urbanisation is giving rise to never previously confronted complications and challenges in African urban management and planning. The 2013 State of Planning in Africa Report [10] affirms this and further outlines challenges faced by African cities in more disconcerting detail. The stated lack of inclusive growth and structural transformation within the African urban landscape have far-reaching consequences and an immense impact on the African urban planning context [5], [18]. It is evident that the contemporary planning context of the global South and Africa unambiguously differs from that within which European planners addressed urbanisation approximately a century ago.

\subsection{African urban residents: "Trumping" the odds?}

In the meantime, whilst planning practitioners and academics are increasingly deliberating an irreversibly and rapidly urbanising global South, with particular concern being voiced regarding the African urban landscape, little attention has been given to the actual urbanising residents, being the cause of this whole discourse. Policy formulation and governmental reaction to this influx, have for a long time aimed at fighting the urbanisation dynamic, rather than working with it [19]. Murray and Myers [20], reprimands that in spite of overwhelming adversities these urbanising residents have proven themselves to be active agents in constructing sustainable human settlements rather than simply being passive victims of 
relentless structural processes beyond their control. In an address [21] to the 2006 World Planners Congress, UN-Habitat Executive Director Anna Tibaijuka, warned that "anti-poor measures" and the belief that "....in the planned city, the poor should at best be hidden or at worst swept away" will exacerbate social exclusion in cities. She also signalled that the "urbanisation of poverty" will be the most imperative future urban issue.

It is clear that a Trump-like "keeping the bad people out" approach cannot be followed the influx of people to African cities will be incessant, the growth of unplanned and informal settlements accumulative, and the attitudes of African planning practitioners and theorists towards this transformation, paramount.

\section{PLETHORA OF PREJUDICE}

"Have no fear of robbers or murderers. They are external dangers, petty dangers. We should fear ourselves. Prejudices are the real robbers; vices the real murderers. The great dangers are within us. Why worry about what threatens our heads or our purses? Let us think instead of what threatens our souls." - Victor Hugo, Les Misérables

Globally the word "informality" or "slum" would involuntarily conjure thoughts of extreme poverty, inadequately serviced and overcrowded, sub-standard urban housing. As a result of an irreversibly urbanising world, informal and unplanned settlements (also commonly referred to as "slums") are extemporaneously emerging as a prevailing type of settlement, particularly in the urban landscapes of developing countries [17]. Various recent UN-Habitat reports [14], [22], have signalled that the global slum population is an ever-growing phenomenon. These reports highlighted inter alia that the global slum population increased on average by six million a year since 2000 , translating into an escalation of about 16,500 persons daily. In Sub-Saharan Africa, 59\% of the current urban population lives in slums.

This situation is not new. The 2003 UN-Habitat report: The challenge of the slums [19], explains that the problems of "high urban densities, low standards of housing and squalor" have been around since humankind first began to live in cities. This is echoed in the Global Report on Human Settlements [23] and Marx et al. [17], stating that slums were a characteristic feature of European and US cities during the Industrial Revolution, a trend which continued well into the twentieth century in some cities. It is manifest that the overcrowded, inadequately serviced slum areas, housing the poorest members of urban society, have long been documented as undesirable traits of urban living. For planning practitioners and academics, though, in pursuit of conceivable responses to the construct of informality, it is almost an impossibility to view these informal settlements and slum-like environments stripped from any kind of prejudice or pejorative connotations.

\section{1 "What's in a name?"}

This notion of "planning prejudice" might be most easily illustrated in the terminology used all over the world to name or describe these informal settlements and slum areas. In an etymology of slum names, Dahlberg [24], contemplates the inherent implications of these "labels" for both planning practitioners and residents. Most of the slum names listed by Dahlberg [24], indicate an intrinsic adverse perception towards these settlements. This include names like "poor villages" (vijiji) in Kenya, "town of thin people" (Saimingai), "area of bad residences" (Furyô jûtaku chîiki), "illegal occupation" (huho sengkyo), "gang of poor people" (hin min kutsu) in Japan, "misery quarters" (Elendsquartier, Elendsviertel) or "poor quarters"(Armenviertel) in Germany, "lost cities" (ciudades perdidas) in Mexico, "misery societies" (villas miseria) in Argentina, "anarchic settlement" (samnong anatepatai) in 
Cambodia, "settlement of rat's houses" (khu nha o chuot) in Vietnam, "dirty areas" (kolache pradesha) or "dirty settlement"(gallicha wasti) in India and "filth neighbourhood" (mahalleye kasif) in Iran.

The Global Report on Human Settlements [23], resonates this, but also cautions that although the word 'slum' is an easily comprehensible "catch-all" term, it masquerades the fact that within this, and other terminology used to describe slum areas, rest a host of diverse settlements and communities. Further to this, the report [23], contends that slums may be divided into two broad classes: 1) slums of hope and 2) slums of despair where the former refers to: "progressing settlements, characterised by new, normally selfbuilt structures, usually illegal (e.g. squatters)" and the latter to "declining neighbourhoods where environmental conditions and domestic services are undergoing a process of degeneration."

\section{2 "Spira, spera (breathe, hope)"}

The preceding classification in itself underlines an inherent prejudice towards slums and a pejorative connotation that influences the planning philosophy for these areas. In his book "Shadow cities", Neuwirth [25] contends that the problem of planning for slums and informal settlements involves much more than finances. Developers have no interest in building for the poor and neither do local and national leaders. Residents in informal settlements or slum areas are frequently neglected and disrespected by governments, politicians, the press and even much of the public. They even often neglect and disrespect themselves as well [25]. Neuwirth charges urban planners and developers to do some selfexamination and to let go of pejorative connotations regarding these settlements, as this masquerades the hopeful planning physiognomies of these landscapes.

Reflecting on Dahlberg's etymology of slum names [24], a selection of these names echoes the residents' hope in being active agents in constructing meaningful lives for themselves rather than simply being passive victims of a plethora of prejudice towards them. Names like "young settlements" (pueblos jovenes) in Peru, "moon village" (daldongnae) or "mountain village" (sandongnae) in South Korea, "village in a city" (chéng zhōngcūn) in China, "rights owned by the people" (Hak milik) in Malaysia, "simulated cities" (bidonvilles) in France and "houses built in moonlight" (tcharacka bet) in Ethiopia, undeniably mirror something about "slums of hope" instead of "slums of despair" and provide a positive platform of departure for planning practitioners and academics.

\section{TABULA RASA}

"An absence of preconceived ideas or predetermined goals; a clean slate..."

Adding to the plethora of prejudice, the African urban landscape has its own unique challenges as outlined in the preceding discussion. In view of this, a number of scholars are questioning the applicability and relevance of planning theory and paradigms asserting generic or global applicability, yet founded in presuppositions about planning, social and economic conditions that are more specific to a global North or Western context. Many of these scholars argue for a unique African planning approach in light of the failure of the African urban landscape to emulate Western models of urbanisation. It is not the purpose of this paper to track the copious accounts of these debates [5], [9], [26]-[28], but rather to focus on the causative position of African urban residents in creating sustainable human settlements, highlighting the instances where they have created unique solutions to planning problems and have shaped the urban landscape to suit their own needs and circumstances, challenging Western rationalities underpinning the said African planning approaches. 


\subsection{The formality of informality}

The formal-informal dichotomy has been widely debated and captured in literature. Many of these debates centre on the issue of defining or classifying informality as opposed to formality [29]. Watson [5], laments that formality and informality is predominantly defined according to Western perceptions of "normal". Lombard and Huxley [30], further substantiates this by arguing that the formal-informal dichotomy often encompasses an "implicit positive appraisal" of formality and a "devaluation" of informality with an escorting postulation that informality is a "Third World" problem, hardly ever associated with Western landscapes. Inevitably the informal is therefore typically associated with "slums", as previously discussed in this paper, and seen as a "problem to be solved" [30], or a "disease to be eradicated."

In planning theory, the inherent influence from the global North is evident as Modernist epitomes are usually expressed in the formal, whilst the irregularities opposing this, are usually framed as the informal [28]. Further to this, Miraftab [31], strongly argues that stressing only the adverse aspects of informality, augments the formal-informal dichotomy and marginalises informality as a construct completely detached from the formal, planned and modern, whilst in reality the binary are interrelated and directly interdependent. Roy [32], agrees in stating that formal planning provokes the informal by distinguishing between activities as formal or informal, legal or illegal.

An eradication development approach towards informality does not take the role of the informal system into consideration. The informal sector came into existence as a result of the inadequacies and inability of the formal sector to accommodate informal residents into formal socio- economic sectors [33]. Calling for the eradication of informal settlements as a development response, stems from a failure to understand why these settlements exist in the first place and how they function [25], [33]. It is essential to recognise the importance of the community networks that exist within the informal sector and how they form an essential component of people's day-to-day lives to provide both a safety net and a sense of community engagement. Residents within informal settlements have put many innovative strategies and mechanisms in place in order to survive, whilst facing serious challenges [33].

\section{2 "Brexiting" African Planning?}

Since urban planning in all parts of the world is undeniably context-driven [5] and culturedefined [34], it should be logical, based on the preceding discussions, that a mere blueprint approach to urban planning in Africa would not be effective. Numerous planning theorists and academics [7], [9], [10], are currently advocating for a unique approach to African urban planning based on the argument that planning theory cannot merely be imported and applied from the global North to the global South, especially in light of the failure of the African urban landscape to emulate Western models of urbanisation and the resulting urban planning responses [35].

However, despite augmented international discourse [36], within the planning academic spheres on this matter, hitherto, governments and planning practitioners in Africa are habitually residing with the known, still endeavouring to apply blueprint copies of the planning principles and theories that were developed in the global North on the metamorphosing urban landscape of Africa [37]. In light of the foregoing discussions, this unchanging approach to African planning, especially within the construct of informality and unplanned settlements, is either very naive or extremely tenacious. 


\subsection{Clean slate planning for Africa: releasing the preconceived approaches}

Healy [26] and Ernstson et al. [27], expressed that varied socio-spatial, economic and environmental constructs demand equally varied planning theories and practical applications. Watson [9] however warns that whilst there is undoubtedly a case for developing an African viewpoint in planning theory, it is also vital to stipulate the limitations on such an endeavour to elude the trap of generating new theoretical binaries.

According to Pieterse [13], the academic literature dealing with urban planning in Africa inclines towards one of three categories:

1. Policy-driven solutions that seek to provide answers within a greater policy determined discourse, based on the assertion that the suggested solutions will be successful should there be enough funding and expertise available;

2. Critical political economy perspectives on current planning approaches within the urban and rural landscape as seen through the prism of capitalism and its consequent state regulation/facilitation; and

3. Ethnographically orientated approaches focussing exhaustively on case studies in order to compensate for and illuminate the lack of social focus displayed by the first two approaches.

Pieterse [13] further cautions that the above-mentioned literature are in many cases functioning in an isolated manner and not providing a holistic perspective on the complex nature and directions of transformation in urban spaces at various scales within the African planning environment. An isolated attempt to understand planning within the African urban landscape in any of the above categories, might have damaging consequences. This paper ultimately argues for a unique qualitative research approach that will release the said preconceived approaches to African planning and take the current literature debate into account, whilst simultaneously capturing the solutions already provided by residents of unplanned settlements in an objective manner, without the subjective influence and criticism of politics and policies.

\section{ABSTRACTING THE ROLE OF AFRICAN URBAN RESIDENTS}

"If the misery of the poor be caused not by the laws of nature, but by our institutions, great is our sin." - Charles Darwin (Voyage of the Beagle)

This section of the paper aims to showcase how African urban residents have proven themselves to be active agents in constructing sustainable human settlements rather than merely being passive victims of inexorable structural processes beyond their control. The research employs theory-based sampling as part of a qualitative inquiry into African urbanism and sustainable human settlement development, making use of case studies in South Africa and Zambia to consider the complexities within these concepts and support the line of argument.

\subsection{The South African reality}

The rapid growth of unplanned and informal settlements, accelerated land invasion, poor-quality housing, a high rate of urban poverty and rapidly increasing inequality in the African urban landscape as mentioned earlier in this paper [4], are all exemplified in the South African landscape [38]. In South Africa these challenges are generally 
exacerbated as a result of a sharpened heritage of colonialism, segregation and more recently, a massive influx of rural-urban migrants to South African cities. Although British colonial influence ceased in 1961 when South Africa gained independence, the urban landscape was plagued by an incessantly racially segregated dispensation until the country became a democracy in 1994 [39]. Correspondingly, according to Odendaal [39], during this period (1961-1994), relatively stable economic growth became an impetus for influx across South African borders and a national migration from rural to urban areas.

These dramatic demographic changes in the South African rural and urban landscapes resulted in the establishment of several unplanned and informal settlements [38] that are increasing at an exponential rate. As a result of this, South Africa became the centre of mounting attention from planning practitioners and academics [13], to "solve this problem" or in more extreme terms, to "eradicate the disease". In the adversity of this unending discourse, excessive bureaucratic rigmarole in the delivery of housing, a failing government and municipal planning system and non-existent service delivery, residents of these unplanned settlements have been labouring non-stop to create sustainable living environments and meaningful lives for themselves. This begs the critical question of the role and interference required from planning practitioners and academics within the rapidly changing South African urban landscape and the resulting unplanned settlements.

\subsection{Planning without planners: some practical examples}

Observing residents of unplanned and informal settlements within the African urban landscape, over a period of 10 years for research and planning practice purposes, resulted in the identification of some practical examples where African urban residents have proven themselves to be active agents in constructing sustainable human settlements and acceptable living environments for themselves. Table 1 provides a sampling of these practical examples, based on case studies areas within South Africa and Zambia. For the purposes of this study this was illustrated by coding and interfacing these case studies with the key attributes of adequate housing and sustainable human settlements as listed by the Urban Sector Network [40] and the Isandla report [33].

Table 1: Abstracting the role of African urban residents: case study examples. (Source: Own construction, 2017.)

\begin{tabular}{|l|l|l|}
\hline \multirow{2}{*}{$\begin{array}{l}\text { Sustainable Human } \\
\text { Settlement attributes }\end{array}$} & \multicolumn{2}{|l|}{ Theory-based sampling } \\
\cline { 2 - 3 } $\begin{array}{l}\text { Adequate shelter/secure } \\
\text { tenure }\end{array}$ & $\begin{array}{l}\text { Makululu shanty } \\
\text { compound, Zambia }\end{array}$ & $\begin{array}{l}\text { Raking their own bricks to build their own } \\
\text { houses }\end{array}$ \\
\hline $\begin{array}{l}\text { Access to basic services } \\
\text { and infrastructure }\end{array}$ & $\begin{array}{l}\text { Makululu shanty } \\
\text { compound, Zambia }\end{array}$ & $\begin{array}{l}\text { Residents manufacture and sell coal to counter } \\
\text { lack of electricity }\end{array}$ \\
\hline $\begin{array}{l}\text { Economic viability/ } \\
\text { affordability }\end{array}$ & $\begin{array}{l}\text { Makululu shanty } \\
\text { compound, Zambia }\end{array}$ & $\begin{array}{l}\text { Residents create economic viability with selling } \\
\text { of home grown vegetables and coal }\end{array}$ \\
\hline $\begin{array}{l}\text { Habitability and health } \\
\text { standards }\end{array}$ & $\begin{array}{l}\text { Makululu shanty } \\
\text { compound, Zambia }\end{array}$ & $\begin{array}{l}\text { Residents provided for their own clinic and } \\
\text { doctor }\end{array}$ \\
\hline $\begin{array}{l}\text { Accessibility/ transport } \\
\text { systems }\end{array}$ & $\begin{array}{l}\text { Marabastad, } \\
\text { Kroonstad, RSA }\end{array}$ & $\begin{array}{l}\text { Residents creating walkways and pedestrian } \\
\text { friendly environment, accessibility to major } \\
\text { transport routes }\end{array}$ \\
\hline $\begin{array}{l}\text { Social integration and } \\
\text { cultural adequacy }\end{array}$ & $\begin{array}{l}\text { Marabastad, } \\
\text { Kroonstad, RSA }\end{array}$ & $\begin{array}{l}\text { Residents creating social friendly interacting by } \\
\text { means of communal areas e.g. soccer field }\end{array}$ \\
\hline $\begin{array}{l}\text { Environmental } \\
\text { sustainability }\end{array}$ & $\begin{array}{l}\text { Edendale: Dambuza } \\
\text { KZN, RSA }\end{array}$ & $\begin{array}{l}\text { Residents started their own recycling project } \\
\text { collecting litter within the settlement }\end{array}$ \\
\hline
\end{tabular}


The examples provided in Table 1 are not exhaustive, but only aims to illustrate the causative position of African urban residents as active agents within the African urban landscape. The solutions they provide might not meet "Western standards" underpinning the creation of sustainable human settlements, but they have contributed with indigenous knowledge and created unique solutions to planning problems and have shaped the urban landscape to suit their own needs and circumstances challenging Western rationalities underpinning African planning approaches.

\section{THE SISTINE CHAPEL OF PLANNING}

"The greater danger for most of us lies not in setting our aim too high and falling short; but in setting our aim too low, and achieving our mark." - Michelangelo

It is common knowledge that when Michelangelo was commissioned to paint the ceiling of the Sistine chapel, he was intimidated by the scale of the assignment and was even apprehensive that such a large-scale project was presented to him by adversaries as a set-up for an inevitable failure [41]. The foregoing discussions in this paper, highlighted the measure of the planning challenges facing the African urban landscape and for many an African planner, practitioner or academic, this might be, or rather should be daunting. The scale of the planning assignment commissioned to African planners is no less intimidating than that of the Sistine chapel painting and it would be foolish to attempt finding a solution in isolation and even worse, in writing only one paper on this topic. This section merely purposes to point to a few nuances in the scope of the African planning landscape that might assist in the quest for workable solutions and ultimately creating better living environments for African urban residents in informal settlements flogged by adversities.

\subsection{Bottom-up meeting top-down}

Even though section 4 of this paper might suggest otherwise, it is important to emphasise that a proposed "tabula rasa" for African planning does not mean the foundation laid by planning theory originating from the global North, should be entirely ignored. Making special mention of, but not limited to, Davidhoff's theory on advocacy and pluralism planning [42], his viewpoint that planning should be "pluralistic" and "represent diverse interests", especially minority interests, underpins the well-established concepts of community planning, participatory planning and bottom-up approaches today. Davidhoff [42], urged urban planners to not endeavour in framing a single plan that denotes the "public interest" but rather "represent and plead the plans of many interest groups." Reverting back to the urban planner truly acting as "advocate" for the community, might be a part of the answer in addressing the disparity between bottom-up not meeting top-down approaches in the African urban landscape. Participatory and community planning as a means to an end and not the end itself, might be the cause of many urban planners merely "going through the motions" during the planning process and not truly advocating for and representing the diverse needs of the African urban communities in unplanned and informal settlements.

\subsection{A new African Planning "philo(love)-sophos(wisdom)"}

The most famous section of the Sistine Chapel ceiling is Michelangelo's Creation of Adam. Many theories exist regarding the identity and meaning of the twelve figures around God in the painting. According to Steinberg [41] the person protected by God's left arm might be 
Sophia, the goddess of wisdom also featuring as one of the primitives in creating the word "philosophy", meaning the love of wisdom. Davidhoff [42], strongly supported intelligent urban planning and argued that "the practice of plural planning requires educating planners who would be able to engage as professional advocates in the contentious work of forming social policy." The preceding discussions on African urban planning underline the notion that the African urban landscape is in desperate need of a new African Planning philosophy - one that would encourage urban planning students, practitioners and academics to pursue new and intelligent ways of planning for marginalised communities in unplanned and informal settlements, striving to take the diverse needs and the causative position of the African urban residents into consideration and to act wisely as advocates representing these urban residents.

\section{3 "The perfect touch"}

Adam's finger almost touching God's in Michelangelo's painting in the Sistine Chapel, most likely rendered the painting its fame. It personifies the almost "perfect touch" and the sensitive balance between life and death [41]. The sensitive positioning of African urban planners in the planning process, and the weight of the responsibility acting as advocates for the African urban community and representing the diverse needs of the urban residents of unplanned and informal settlements, requires wisdom and intelligent decision making.

At the 2006 World Planners Congress, UN-Habitat Executive Director Anna Tibaijuka called on planning practitioners and academics to develop a different approach to planning: one that is pro-poor and inclusive and that centres on the creation of livelihoods [21]. For African urban planners, practitioners and academics this implies a complete African planning metamorphosis. Concluding the arguments in this paper, this sensitive role and balance of the African planner in the planning process would require the following six finer touches/nuances to African urban planning:

1. Accepting, and moreover, welcoming the rapidly changing African urban landscape and the resulting planning environment;

2. Unprejudiced consideration of the informal settlements and slum-like circumstances resulting from this rapidly urbanising landscape.

3. Recognising slums/unplanned/informal settlements as areas with social and economic potential - places of hope and not despair.

4. Releasing the preconceived approaches and starting from a clean slate when planning within an African context.

5. Abstracting the role of African urban residents and recognising their causative position in creating sustainable human settlements.

6. Striving towards becoming a wise and intelligent planner, truly advocating for the diverse needs of communities and fulfilling the sensitive role of balancing the touching point between bottom-up and top-down approaches.

\section{ACKNOWLEDGEMENTS}

I wish to thank various people for their contribution to this paper; Juanee Cilliers and Christi Niesing for their professional guidance and valuable support, Jako Viviers for his constructive recommendations, for keeping the humor and supplying most of the "catch phrases" and Marnus Botha for his assistance in collecting pictures of the case study areas. 


\section{REFERENCES}

[1] United Nations. Department of Economic and Social Affairs. World urbanization prospects: the 2014 revision, highlights. New York, 2014.

[2] Freire, M., Urban panning: challenges in developing countries. (Paper presented at the International Congress on Human Development, Madrid), 2006.

[3] Human Development Agency, 2012. South Africa: informal settlement status. http://thehda.co.za/pdf/uploads/multimedia/HDA_Informal_settlements_status_South Africa.pdf. Accessed on: 30 Jun. 2017.

[4] Adesina, A.A., Gurria, A., Helen, C., eds. African economic outlook: sustainable cities and structural transformation. Paris: OECD Publications, 2016.

[5] Watson, V., "The planned city sweeps the poor away...": Urban planning and 21st century urbanisation. Progress in Planning, 72, pp. 151-193, 2009.

[6] Silva, C.N., Urban Planning in Sub-Saharan Africa: an overview. [Routledge]. pp. 841, 2015.

[7] Watson, V., Seeing from the South: Refocusing Urban Planning on the Globe's Central Urban Issues. Urban Studies, 46(11), pp. 2259-2275, 2009.

[8] Pieterse, E. \& Rode, P., African Urbanism. https://lsecities.net/media/objects/events/2011-01-26-african-urbanism. Accessed on: 29 Jun. 2017. [Podcast], 2011.

[9] Watson, V., African urban fantasies: dreams or nightmares? Environment and Urbanization, 26(1), pp. 215-231, 2014.

[10] Waheed, K., Kabir, Y., Ashaf, A., et al., The state of planning in Africa. https://unhabitat.org/books/the-state-of-planning-in-africa-an-overview/. Accessed on: 26 Jun. 2017, 2013.

[11] Turok, I., 2015. Informal settlements: poverty traps or ladders to work? http://www.econ3x3.org/article/informal-settlements-poverty-traps-or-ladders-work. Accessed on: 30 Jun. 2017.

[12] UN-Habitat, The state of African cities - re-imagining sustainable urban transitions. Kenya: UN-Habitat, 2014.

[13] Pieterse, E., Explanatory notes on African Urbanism. (Unpublished), 2009.

[14] UN-Habitat. Slum almanac 2015/2016 - tackling improvement in the lives of slum dwellers. https://unhabitat.org/wp-content/uploads/2016/02-old/Slum\%20Almanac\% 202015-2016_EN.pdf. Accessed on: 30 Jun 2017.

[15] UN-Habitat, World cities report 2016 - Urbanization and development: emerging futures. Kenya: UN-Habitat, 2016.

[16] United Nations, Department of Economic and Social Affairs. World economic and social survey 2013: sustainable development challenges. New York, 2013.

[17] Marx, B., Stoker, T. \& Suri, T., The economics of slums in the developing world. Journal of Economic Perspectives, 27(4), pp. 187-210, 2013

[18] SACN, State of South African cities report 2016. Johannesburg: SACN, 2016.

[19] UN-Habitat, The challenge of slums - global report on human settlements 2003. London: Earthscan Publications, 2003.

[20] Murray, M.J. \& Myers, G. 'Introduction', in Murray, M.J. \& Myers, G. eds., Cities in Contemporary Africa. New York: Palgrave Macmillan, 2006.

[21] Tibaijuka, A., Inaugural address. Proceedings of the World Planners Congress, 2006.

[22] UN-Habitat. Habitat III issue papers: 22 - Informal settlements. https://unhabitat.org/habitat-iii-issue-papers-22-informal-settlements/. Accessed on: 29 Jun. 2017. 
[23] UN-Habitat, Planning Sustainable Cities - Global Report on Human Settlements. Kenya: UN-Habitat, 2009.

[24] Dahlberg, G., An Etymology of Slum Names. African Cities Reader: Land, Property and Value, 3(1), pp. 148-152, 2015.

[25] Neuwirth, R., Shadow Cities: A Billion Squatters, a New Urban World. New York: [Routledge], p. 335, 2005.

[26] Healey, P., The universal and the contingent: Some reflections on the transnational flow of planning ideas and practices. Planning Theory, 11(2), pp. 188-207, 2012.

[27] Ernstson, H., Lawhon, M. \& Duminy, J., Conceptual Vectors of African Urbanism: 'Engaged Theory-Making' and 'Platforms of Engagement'. Regional Studies, 48(9), pp. 1563-1577, 2014.

[28] Watson, V., The usefulness of normative planning theories in the context of SubSaharan africa. Planning Theory, 1(1), pp. 27-52, 2002.

[29] Porter, L., Informality, the Commons and the Paradoxes for Planning: Concepts and Debates for Informality and Planning Self-Made Cities: Ordinary Informality? Planning Theory \& Practice, 12(1), pp. 115-153, 2011.

[30] Lombard, M. \& Huxley, M., Self-Made Cities: Ordinary Informality? Planning Theory \& Practice, 12(1), pp. 120-125, 2011.

[31] Miraftab, F., Insurgent planning: Situating radical planning in the global south. Planning Theory, 8(1), pp. 32-50, 2009.

[32] Roy, A., Postcolonial urbanism: speed, hysteria, mass dreams. In Roy, A. \& Ong, A., eds. Worlding cities: Asian experiments and the art of being global. Oxford: WileyBlackwell, pp. 307-335, 2014.

[33] Isandla, Do informal land markets work for poor people: An assessment of three metropolitan cities in South Africa. Pretoria: Urban LandMark, 2007.

[34] Friedmann, J, Review: Globalization and the emerging culture of planning. Progress in Planning, (64), pp. 183-234, 2005.

[35] Watson, V., Engaging with Citizenship and Urban Struggle Through an Informality Lens. Planning Theory and Practice, 12(1), pp. 150-153, 2011.

[36] Harrison, P., On the edge of reason: Planning and urban futures in Africa. Urban Studies [Routledge], 43(2), pp. 319-335, 2006.

[37] Watson, V., Shifting approaches to planning theory: global North and South. Urban Planning, 1(4), pp. 32-41, 2016.

[38] Turok, I., Urbanization and development on South Africa: economic imperatives, spatial distortions and strategic responses. London: International Institute for Environment and Development, 2012.

[39] Odendaal, N., Reality check: Planning education in the African urban century. Cities, 29, pp. 174-82, 2012.

[40] Urban sector network, Expanding socio-economic rights and access to housing. Prepared for USAID. Johannesburg: Urban Sector Network, 2003.

[41] Steinberg, L., "Who's Who in Michelangelo's Creation of Adam: A Chronology of the Picture's Reluctant Self-Revelation." Art Bulletin pp. 552-566, 1992.

[42] Davidoff, P., Advocacy and pluralism in planning. Journal of the American Institute for Planners, 31(4), pp. 331-338, 1965. 